\title{
Nutritional composition of different size groups of catfish Rita rita (Hamilton, 1822) from river Ganga
}

\author{
T. MITRA, S. GANGULY, S. BANERJEE, A. MAHANTY, R. K. RAMAN, S. BHOWMICK \\ AND B. P. MOHANTY* \\ "ICAR-Central Inland Fisheries Research Institute, Barrackpore, Kolkata - 700 120, West Bengal, India \\ e-mail: bimalmohanty12@rediffmail.com
}

\begin{abstract}
The freshwater catfish Rita rita (Hamilton, 1822) (Family: Bagridae) inhabits the tropical rivers and estuaries and contributes to the capture fisheries production in the Indian subcontinent. It enjoys high consumer preference as a valuable food fish due to its muscle texture, good taste and lesser intramuscular spines; however, basic nutritional information on the species is not available. In the present study, we report the proximate composition, amino acid, fatty acid and mineral composition of different size groups of $R$. rita. Proximate analysis showed that the fish is rich in protein and low in fat. The protein content (19.55\%) was found to be the highest in medium size fishes. Leucine, phenylalanine and glutamic acid are the predominant amino acids in all size groups and

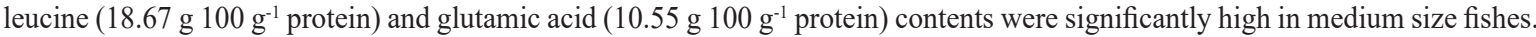
The macro-minerals potassium (13800 ppm) and phosphorous (14100 ppm) were significantly high in the medium size group, whereas calcium $(1900 \mathrm{ppm})$ was highest in large size group. The micro-minerals iron and zinc were present in significantly higher amount in the medium size fishes. $R$. rita is important as a rich source of protein, essential amino acids (leucine, phenylalanine, glutamic acid) and micro elements ( $\mathrm{n}, \mathrm{Fe}$ ). Comparative nutritional evaluation of different size groups showed that the medium size fish (weighing 500-800 g) were nutritionally superior to the other groups.
\end{abstract}

Keywords: Amino acids, Fatty acids, Minerals, Nutritional composition, Rita rita

\section{Introduction}

Rita rita, an important member of Bagridae family, contributing significantly to riverine fisheries in the Indian subcontinent (Noor et al., 2013), enjoys high consumer preference as a valuable food fish due to its muscle texture, good taste and lesser intramuscular spines. The meat quality and texture is mainly determined by factors such as muscle protein content, organisation and composition (Picard et al., 2012). Earlier, we generated information on muscle proteome profile and functional genomics aspects of this catfish and identified proteins in muscle proteome associated with muscle texture, flesh quality such as elasticity, firmness and water holding capacity, which could possibly be linked to its taste and high consumer preference (Mohanty et al., 2015). Fish is an important source of multiple nutrients including essential amino acids, fatty acids and micronutrients that are essential for human health and nutrition (Nguyen et al., 2004; Mohanty et al., 2014). Amino acids are important molecules that both serve as building blocks of proteins and regulate key metabolic pathways to improve health, survival, growth, development, lactation and reproduction of organisms $(\mathrm{Wu}$, 2009; Mohanty et al., 2014). Similarly, fatty acids play crucial role in maintaining health and cellular functions. Minerals are required in very trace amount; however, they are essential for maintaining proper homeostasis in the body like health, development, growth (Mahanty et al., 2014; Mohanty et al., 2016). As information on the nutrients in this species is meagre, in the present study we investigated the nutritional composition of the species and how it can contribute to nutritional security. As the taste, nutrition, muscle composition and quality of fish meat are known to vary with age and growth, comparative nutrient profiling of three different size groups of the species was undertaken.

\section{Materials and methods}

Sample collection

The fish were collected from river Ganga at Allahabad in post-monsoon period (August-September, 2014) and transported in ice to the laboratory. The individual length $(\mathrm{cm})$ and weight $(\mathrm{g})$ of the fishes were recorded. They were divided into three groups based on body weight and length as small (200-400 g, 20-30 cm), medium (500-800 g, 30-40 cm) and large (1200-1800 g, 40-45 cm).

\section{Proximate composition}

Fish were cleaned, degutted, edible muscles were filleted and stored at $40^{\circ} \mathrm{C}$ until analysis. The proximate composition (moisture, crude fat, crude protein and ash) 
were determined as per standard protocol (AOAC, 2006). Fish fillets of small $(n=10)$, medium $(n=10)$ and large $(n=10)$ size groups were homogenised with the help of a mixer grinder. The minced samples were kept in an oven at $105 \pm 2{ }^{\circ} \mathrm{C}$ overnight until constant weight was obtained. The crude protein and crude fat contents were estimated by Kjeldahl and Soxhlet methods, respectively (AOAC, 2006). Ash was obtained after incineration of moisture free dry sample in a muffle furnace at $600^{\circ} \mathrm{C}$ for $6 \mathrm{~h}$ until weight became constant. The ash content was determined gravimetrically and expressed as percentage.

\section{Amino acids}

Amino acid composition was determined following standard protocol (Ishida et al., 1981) and has been described earlier (Mohanty et al., 2012). Briefly, $50 \mathrm{mg}$ muscle samples of individual fishes from small, medium and large size category were hydrolysed with $6 \mathrm{~N}$ hydrochloric acid at $110^{\circ} \mathrm{C}$ under anaerobic condition for $12 \mathrm{~h}$. The hydrolysed samples were neutralised with $6 \mathrm{~N} \mathrm{NaOH}$ and were derivatised using a kit (AccQ-Fluor Reagent, WAT052880, Waters). The derivatised samples were injected in HPLC (1525, Waters) equipped with a $\mathrm{C}_{18} \mathrm{RP}$ column and a fluorescence detector (2475, Waters) with excitation and emission wavelengths $250 \mathrm{~nm}$ and $395 \mathrm{~nm}$, respectively. The amino acids were identified and quantified by comparing the retention times and peak areas of standards (WAT088122, Waters). For tryptophan analysis, $50 \mathrm{mg}$ minced meat was digested with 5\% (w/v) $\mathrm{NaOH}$ for $12 \mathrm{~h}$ and neutralised to $\mathrm{pH} 7.0$ with $6 \mathrm{~N} \mathrm{HCl}$. Tryptophan content was measured using spectrophotometer at $530 \mathrm{~nm}$ (Sastry and Tammuru, 1985).

\section{Fatty acids}

Total lipid of the fish was extracted following the standard protocol (Folch et al., 1957). Briefly, $30 \mathrm{~g}$ wet fish muscle was homogenised with 2:1 mixture of chloroform and methanol to extract the total lipid content of the tissue. Fatty acid methyl esters (FAMEs) were prepared by transesterification with boron trifluoride $\left(\mathrm{BF}_{3}\right)$ in methanol from lipid fraction according to standard protocol (Metcalfe et al., 1966). The FAMEs were quantified by injecting $0.5 \mu 1$ (30:1 split ratio) into GC-MS column, and identified using a GC (Trace GC Ultra, Thermo Scientific) equipped with a capillary column (TR FAME $30 \mathrm{~m} \times 0.25 \mathrm{~mm}, 0.25 \mu \mathrm{m}$ film thickness) and an MS attached to it. The individual constituents showedby GC-MSwereidentifiedandquantifiedbycomparing the retention times and peak areas to those of standards (ME-14-KT and ME-19-KT, SUPELCO Analytical).

\section{Minerals}

Fish samples of different size groups were analysed in ICP spectrometer (iCAP 6300 Radial, Thermo Scientific) after digesting the samples using nitric acid and hydrogen peroxide in a microwave oven. Quantification was done by comparing with multi-element standard IV, MERCK (NIST) for sodium, potassium, calcium, magnesium, iron, copper, zinc and manganese and Trace Cert (NIST) for phosphorous.

\section{Statistical analysis}

Results were subjected to analysis of variance (ANOVA) using SPSS 16.0 software. Level of significance was established at $5 \%$ level.

\section{Results and discussion}

\section{Proximate composition}

The proximate composition of different size groups of R. rita are presented in Table 1. The average moisture, crude protein, crude fat and ash content of different size groups of fishes were estimated to be $79.09,18.12,1.78$ and $1.00 \%$, respectively. Protein content of $R$. rita ranged between 17.2-19.55\%. Protein content of medium size (19.55\%) group was comparatively higher than other size groups and Indian major carps (IMCs), Labeo rohita (12.84\%) (Ahmed, $2011)$ and similar to Cirrhinus mrigala (19.10\%) and Catla catla (19.60\%) (Gopakumar, 1997). Average protein content of $R$. rita $(18.12 \%)$ was higher than that of many other catfishes like Mystus vittatus (15.62\%), Clarias batrachus (14.78\%), Wallago attu (17.00\%) and is similar to bagridae catfish Sperata aor (19.05\%) (Kamal et al., 2007; Memon et al., 2010) and Sperata seenghala (20.06\%) (Mohanty et al., 2012). Crude fat content was significantly higher in large size fish and fat content in all the three size groups were lower as compared to other catfishes such as Heteropneustes fossilis (3.45\%), C. batrachus (7.90\%), M. vittatus (7.53\%) and L. rohita (4.33\%) (Ramani et al., 2002). However, ash content in different size groups of $R$. rita was similar to that of other members of the Bagridae family, S. aor (1.78\%) (Kamal et al., 2007; Memon et al., 2010) and S. seenghala (1.40\%) (Mohanty et al., 2012).

\section{Amino acid composition}

The amino acid profiles of different size groups of $R$. rita are presented in Table 2. The sum of total essential

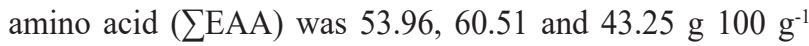
protein in small, medium and large size groups, respectively. EAA content was found to be the highest in medium size groups.

Among the amino acids in $R$. rita, essential amino acid leucine was the predominant one and it was present in significantly high amount in medium size fishes $(18.67 \mathrm{~g}$ $100 \mathrm{~g}^{-1}$ protein). Leucine is the only dietary amino acid that can stimulate muscle protein synthesis and has important role in stress conditions like burn, trauma, and sepsis (Mohanty et al., 2014). Leucine content of $R$. rita is more than double the amount as compared to other 
Table 1. Proximate composition of different size groups of Rita rita

\begin{tabular}{lllll}
\hline \multirow{2}{*}{ Proximate composition (\%) } & \multicolumn{3}{c}{ Size group } \\
\cline { 2 - 5 } & Small & Medium & Large & Average \\
\hline Moisture & $80.32 \pm 0.99^{\mathrm{a}}$ & $77.76 \pm 0.06^{\mathrm{ab}}$ & $79.19 \pm 0.52^{\mathrm{a}}$ & $79.09 \pm 1.28$ \\
Crude protein & $17.59 \pm 1.02^{\mathrm{a}}$ & $19.55 \pm 1.22^{\mathrm{a}}$ & $17.22 \pm 0.60^{\mathrm{a}}$ & $18.12 \pm 1.25$ \\
Crude fat & $1.01 \pm 0.03^{\mathrm{a}}$ & $1.65 \pm 0.08^{\mathrm{b}}$ & $2.70 \pm 0.12^{\mathrm{c}}$ & $1.78 \pm 0.85$ \\
Ash & $1.07 \pm 0.08^{\mathrm{a}}$ & $1.04 \pm 0.14^{\mathrm{a}}$ & $0.89 \pm 0.06^{\mathrm{a}}$ & $1.00 \pm 0.09$ \\
\hline
\end{tabular}

Values are presented as mean \pm standard deviation

Different superscripts within a row correspond to significant difference $(\mathrm{p}<0.05)$

Table 2. Amino acid composition of different size groups of Rita rita

\begin{tabular}{|c|c|c|c|c|}
\hline \multirow{2}{*}{ Amino acids (g $100 \mathrm{~g}^{-1}$ protein) } & \multicolumn{4}{|c|}{ Size group } \\
\hline & Small & Medium & Large & Average \\
\hline \multicolumn{5}{|l|}{ Essential amino acids (EAA) } \\
\hline Arginine & $6.50 \pm 0.47^{\mathrm{a}}$ & $4.58 \pm 0.73^{b}$ & $1.88 \pm 0.07^{\mathrm{c}}$ & $4.30 \pm 2.20$ \\
\hline Histidine & $5.38 \pm 0.43^{\mathrm{a}}$ & $5.69 \pm 1.50^{\mathrm{a}}$ & $1.14 \pm 0.30^{\mathrm{b}}$ & $4.02 \pm 2.51$ \\
\hline Isoleucine & $6.42 \pm 0.17^{\mathrm{a}}$ & $2.49 \pm 0.21^{\mathrm{b}}$ & $6.87 \pm 0.60^{\mathrm{a}}$ & $4.66 \pm 2.07$ \\
\hline Leucine & $14.66 \pm 2.87^{\mathrm{a}}$ & $18.67 \pm 0.22^{\mathrm{b}}$ & $14.62 \pm 1.34^{\mathrm{a}}$ & $17.06 \pm 2.15$ \\
\hline Lysine & $3.53 \pm 0.38^{\mathrm{a}}$ & $8.51 \pm 0.05^{\mathrm{b}}$ & $1.13 \pm 0.26^{\mathrm{c}}$ & $4.38 \pm 3.77$ \\
\hline Threonine & $3.84 \pm 0.96^{\mathrm{a}}$ & $5.64 \pm 0.22^{\mathrm{b}}$ & $1.59 \pm 0.28^{\mathrm{a}}$ & $3.91 \pm 1.70$ \\
\hline Methionine & $4.99 \pm 3.21^{\mathrm{a}}$ & $6.85 \pm 0.03^{\mathrm{a}}$ & $5.32 \pm 0.46^{\mathrm{a}}$ & $4.62 \pm 2.65$ \\
\hline Phenylalanine & $9.65 \pm 0.81^{\mathrm{a}}$ & $9.16 \pm 0.66^{\mathrm{a}}$ & $9.77 \pm 0.61^{\mathrm{a}}$ & $9.41 \pm 0.32$ \\
\hline *Tryptophan & $0.06 \pm 0.01^{\mathrm{a}}$ & $0.06 \pm 0.01^{\mathrm{a}}$ & $0.07 \pm 0.01^{\mathrm{a}}$ & $0.06 \pm 0.00$ \\
\hline Tyrosine & $1.76 \pm 0.34^{\mathrm{a}}$ & $2.03 \pm 0.30^{\mathrm{a}}$ & $2.33 \pm 0.48^{\mathrm{a}}$ & $2.07 \pm 0.24$ \\
\hline Valine & $5.43 \pm 1.49^{\mathrm{a}}$ & $3.44 \pm 0.05^{\mathrm{b}}$ & $2.74 \pm 0.29^{b}$ & $4.41 \pm 2.30$ \\
\hline Cysteine & $0.56 \pm 0.52^{\mathrm{a}}$ & $0.45 \pm 0.69^{\mathrm{a}}$ & $0.65 \pm 0.10^{\mathrm{a}}$ & $0.57 \pm 0.10$ \\
\hline Glutamic acid ${ }^{1}$ & $6.19 \pm 0.15^{\mathrm{a}}$ & $10.55 \pm 0.21^{\mathrm{b}}$ & $1.90 \pm 0.60^{\mathrm{c}}$ & $6.18 \pm 4.32$ \\
\hline Glycine $^{1}$ & $5.35 \pm 2.39^{\mathrm{a}}$ & $6.40 \pm 2.48^{\mathrm{a}}$ & $4.93 \pm 0.19^{\mathrm{a}}$ & $5.41 \pm 0.85$ \\
\hline Proline $^{1}$ & $1.73 \pm 0.27^{\mathrm{a}}$ & $1.86 \pm 10.58^{\mathrm{a}}$ & $0.25 \pm 0.25^{\mathrm{b}}$ & $1.27 \pm 0.89$ \\
\hline$\sum$ EAA & 72.15 & 86.32 & 55.12 & 72.26 \\
\hline \multicolumn{5}{|l|}{ Non-essential amino acids (EAA) } \\
\hline Alanine & $4.26 \pm 0.10^{\mathrm{a}}$ & $6.62 \pm 0.06^{\mathrm{b}}$ & $6.61 \pm 0.21^{\mathrm{b}}$ & $5.83 \pm 1.36$ \\
\hline Aspartic acid & $1.46 \pm 0.43^{\mathrm{a}}$ & $4.61 \pm 0.85^{\mathrm{b}}$ & $2.76 \pm 0.43^{\mathrm{c}}$ & $2.94 \pm 1.58$ \\
\hline Serine & $1.93 \pm 0.17^{\mathrm{a}}$ & $0.97 \pm 0.06^{\mathrm{b}}$ & $1.59 \pm 0.41^{\mathrm{a}}$ & $1.49 \pm 0.48$ \\
\hline$\sum \mathrm{NEAA}$ & 7.65 & 12.20 & 10.97 & 10.27 \\
\hline
\end{tabular}

Values are presented as mean \pm standard deviation

Different superscripts within a row correspond to significant difference $(\mathrm{p}<0.05)$

* Tryptophan content was measured using spectrophotometer at $530 \mathrm{~nm}$.

EAA- essential amino acid as per human nutrition (Wu, 2009)

NEAA- non-essential amino acid (Wu, 2009)

${ }^{1}$ Conditionally essential amino acids (Wu, 2009)

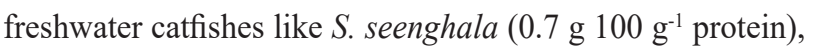

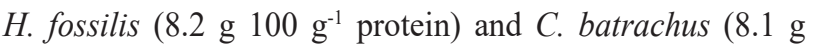

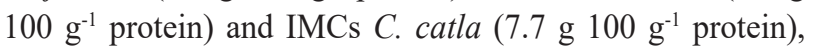

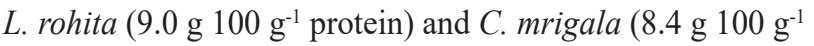
protein). Phenylalanine was found to be the predominant amino acid followed by leucine. Phenylalanine content of

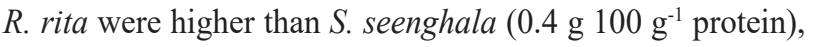

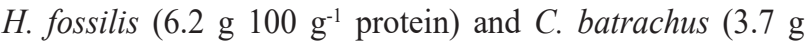
$100 \mathrm{~g}^{-1}$ protein). $R$. rita was found to contain fair amount of glutamic acid irrespective of its size variation which was higher than giant catfish S. seenghala (1.6 g $100 \mathrm{~g}^{-1}$ protein) but lower than IMCs C. catla (13.8 g $100 \mathrm{~g}^{-1}$ protein), L. rohita (14.6 g $100 \mathrm{~g}^{-1}$ protein), C. mrigala (14.8 g $100 \mathrm{~g}^{-1}$ protein)

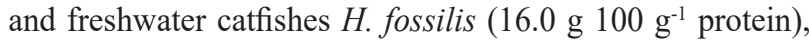
and C. batrachus (14.5 g $100 \mathrm{~g}^{-1}$ protein) (Mohanty et al., 2014). A comparative view of leucine and phenylalanine content in $R$. rita as compared to other major catfishes and IMCs are shown in Fig. 1. Among non-essential amino 


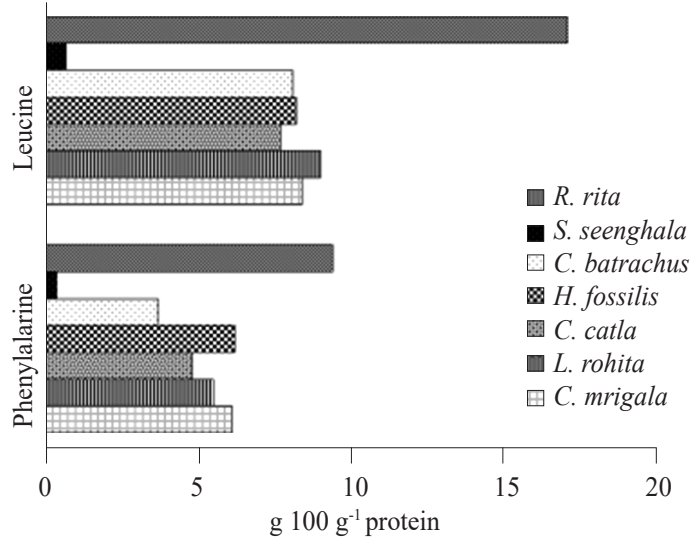

Fig. 1. Comparison of essential amino acids (leucine and phenylalanine) content of Rita rita with other catfishes (S. seenghala, H. fossilis, C. batrachus) and the Indian major carps C. catla, L. rohita and C. mrigala. For comparison, average of leucine and phenylalanine content of three size groups of $R$. rita has been used. Data for S. seenghala, $H$. fossilis, C. batrachus and the Indian major carps C. catla, L. rohita and C. mrigala has been taken from Mohanty et al., (2014)

acids, alanine and aspartic acid were the dominant amino acids in $R$. rita. In an earlier study, we reported the amino acid composition of 27 food fishes from India, discussed the richness of specific species for different amino acids and their importance in clinical nutrition (Mohanty et al., 2014). The present investigation adds further to the list, strengthening the knowledge base and based on the amino acid profile of $R$. rita, the fish can be recommended in clinical conditions related to leucine and phenylalanine requirement such as burn trauma and sepsis (Etzel, 2004; Bandt and Cynober, 2006).

\section{Fatty acid composition}

The fatty acid composition of different size groups of R. rita are presented in Table 3. GC-MS fingerprint of fatty acid profile shows that the sum of total saturated fatty acid ( $\sum \mathrm{SFA}$ ) content in small, medium and large size fishes were $20.82,26.59$ and $24.05 \%$ respectively SFA content was lower in small fishes. Monounsaturated fatty acid (MUFA) was found to increase with size of fish (small $41.91 \%$, medium $47.52 \%$ and large $49.37 \%$ ). Total polyunsaturated fatty acid (PUFA) distribution was highest in small fishes (12.1\%).

Among SFA, palmitic acid (C16:0) was found to be the dominant $(11.02 \%)$ as in other catfishes like the channel catfish Ictalurus punctatus (19.2\%), Pangasianodon hypophthalmus (42.63\%) (Ho and Paul 2009), S. seenghala $(21.10 \%)$ (Mohanty et al., 2012) and rainbow trout (Oncorhynchus mykiss) (21.3\%) (Ho and Paul, 2009). Oleic acid (C18:1) was found to be the major MUFAs; however, it was found to be lower in R. rita as compared to other catfishes like S. seenghala (28.36\%) (Mohanty et al., 2012) and P. hypophthalmus (34.69\%) (Ho and Paul, 2009). The level of docosahexaenoic acid (DHA) (C22:6) was 3.97\%, which was the highest among all PUFAs, followed by eicosapentaenoic acid (EPA) (C20:5), and arachidonic acid (C20:4). The amount of EPA and DHA was $7.90 \%$. which was less than the catfish S. seenghala (10.56\%) (Mohanty et al., 2012) and small indigenous fish Puntius sophore (9.47\%) (Mahanty et al., 2014).

\section{Mineral content}

Minerals are required in very trace amount; but, they are vital for maintaining proper homeostasis in the body. Minerals that were detected in $R$. rita are sodium $(\mathrm{Na})$, potassium $(\mathrm{K})$, calcium $(\mathrm{Ca})$, magnesium $(\mathrm{Mn})$, phosphorous (P) (macro minerals) as well as iron $(\mathrm{Fe})$, zinc $(\mathrm{Zn})$ and manganese $(\mathrm{Mg})$ (micro minerals). The mineral profiles of R. rita are presented in Table 4.

The mineral contents were found to vary significantly $(\mathrm{p}<0.05)$ in different size groups of the fish, except for $\mathrm{Mg}$. The sodium, potassium, phosphorous and zinc contents were higher in medium size group than the other size groups whereas calcium and iron contents were higher in large and small size groups, respectively. Among the macro-minerals, potassium was predominant followed by phosphorous, sodium, calcium and magnesium. Potassium content in all the three size groups of $R$. rita was higher than other catfishes viz., S. seenghala (13780.01 ppm) (Mohanty et al., 2012), H. fossilis (1864.67 ppm) and C. batrachus (2621.04 ppm) (Mohanty et al., 2016) and almost two times higher than that of the nutrient dense small indigenous fish, P. sophore (2283.7 ppm) (Mahanty et al., 2014). Similarly, phosphorus content was almost ten times higher in R. rita $(13333.0 \mathrm{ppm})$ than other catfishes, C. batrachus (1300.59 ppm) and H. fossilis (1070.09 ppm) (Noor et al., 2013). Sodium content was also significantly high in medium size fishes like potassium. Average sodium content was higher in $R$. rita $(2700 \mathrm{ppm})$ than other catfishes, S. seenghala (1983.11 ppm), H. fossilis (2040.38 ppm) and C. batrachus (2080.00 ppm) (Mohanty et al., 2016). Calcium content was significantly high in large fishes (1900.00 ppm) and it was higher than Indian major carp L. rohita $(862.8 \mathrm{ppm})$ but lower in comparison to $S$. seenghala (4581.15 ppm) (Mohanty et al., 2012), H. fossilis (1950.35 ppm) and C. batrachus (2250.75 ppm) (Gopakumar, 1997; Mohanty et al., 2016).

Iron was found to be the predominant micromineral in $R$. rita and was higher than in S. seenghala (45.1 ppm), C. batrachus (18.9 ppm) and H. fossilis (27.1 ppm)and the Indianmajorcarps(IMCs),C.catla(16ppm), L. rohita $(22 \mathrm{ppm})$ and C. mrigala (3 ppm) (Ho and Paul, 2009) irrespective of its size variation. Thus, $R$. rita can be recommended as a dietary supplement in clinical conditions related to iron deficiency such as anaemia, impaired brain function and in infants suffering from poor learning ability 
Table 3. Fatty acid composition of different size groups of Rita rita

\begin{tabular}{|c|c|c|c|c|}
\hline Fatty acids ( $\%$ of total area) & Small & Medium & Large & Average \\
\hline \multicolumn{5}{|l|}{ Saturated fatty acids (SFA) } \\
\hline Caproic (C6:0) & $0.14 \pm 0.03^{\mathrm{a}}$ & $1.09 \pm 0.15^{\mathrm{b}}$ & $1.30 \pm 0.20^{\mathrm{b}}$ & $0.84 \pm 0.62$ \\
\hline Caprylic (C8:0) & $0.06 \pm 0.02^{\mathrm{a}}$ & $0.29 \pm 0.03^{\mathrm{b}}$ & $0.01 \pm 0.00^{\mathrm{c}}$ & $0.12 \pm 0.15$ \\
\hline Pelargonic (C9:0) & $0.29 \pm 0.04^{\mathrm{a}}$ & $1.65 \pm 0.15^{\mathrm{b}}$ & $0.51 \pm 0.18^{\mathrm{a}}$ & $0.82 \pm 0.73$ \\
\hline Capric $(\mathrm{C} 10: 0)$ & $0.15 \pm 0.08^{\mathrm{a}}$ & $0.68 \pm 0.06^{\mathrm{b}}$ & $0.17 \pm 0.10^{\mathrm{a}}$ & $0.33 \pm 0.30$ \\
\hline Undecylic (C11:0) & $0.62 \pm 0.05^{\mathrm{a}}$ & $1.07 \pm 0.20^{\mathrm{b}}$ & $0.74 \pm 0.10^{\mathrm{a}}$ & $0.81 \pm 0.23$ \\
\hline Lauric (C12:0) & $3.64 \pm 0.58^{\mathrm{a}}$ & $2.69 \pm 0.37^{\mathrm{b}}$ & $1.37 \pm 0.10^{\mathrm{c}}$ & $2.57 \pm 1.14$ \\
\hline Tridecylic (C13:0) & $0.34 \pm 0.07^{\mathrm{b}}$ & $0.19 \pm 0.02^{\mathrm{a}}$ & $0.16 \pm 0.03^{\mathrm{a}}$ & $0.23 \pm 0.10$ \\
\hline Myristic (C14:0) & $0.56 \pm 0.15^{\mathrm{a}}$ & $0.88 \pm 0.06^{\mathrm{b}}$ & $0.92 \pm 0.15^{\mathrm{b}}$ & $0.79 \pm 0.20$ \\
\hline Pentadecylic (C15:0) & $0.19 \pm 0.01^{\mathrm{b}}$ & $0.17 \pm 0.02^{\mathrm{a}}$ & $0.20 \pm 0.01^{\mathrm{b}}$ & $0.19 \pm 0.02$ \\
\hline Palmitic(C16:0) & $9.24 \pm 0.35^{\mathrm{a}}$ & $11.51 \pm 0.20^{\mathrm{b}}$ & $12.32 \pm 0.56^{\mathrm{b}}$ & $11.02 \pm 1.60$ \\
\hline Margaric (C17:0) & $0.45 \pm 0.04^{\mathrm{b}}$ & $0.29 \pm 0.02^{\mathrm{a}}$ & $0.35 \pm 0.04^{\mathrm{a}}$ & $0.36 \pm 0.08$ \\
\hline Stearic $(\mathrm{C} 18: 0)$ & $3.80 \pm 0.14^{\mathrm{a}}$ & $4.01 \pm 0.31^{\mathrm{a}}$ & $4.07 \pm 0.15^{\mathrm{a}}$ & $3.96 \pm 0.14$ \\
\hline Nonadecylic (C19:0) & $0.01 \pm 0.00^{\mathrm{a}}$ & $0.04 \pm 0.01^{\mathrm{ab}}$ & $0.13 \pm 0.09^{\mathrm{b}}$ & $0.06 \pm 0.06$ \\
\hline Arachidic (C20:0) & $0.02 \pm 0.01^{\mathrm{a}}$ & $0.01 \pm 0.00^{\mathrm{a}}$ & $0.01 \pm 0.00^{\mathrm{a}}$ & $0.01 \pm 0.00$ \\
\hline Heneicosylic (C21:0) & $0.14 \pm 0.17^{\mathrm{a}}$ & $0.14 \pm 0.18^{\mathrm{a}}$ & $0.35 \pm 0.24^{\mathrm{a}}$ & $0.21 \pm 0.12$ \\
\hline Behenic $(\mathrm{C} 22: 0)$ & $0.42 \pm 0.32^{\mathrm{a}}$ & $1.18 \pm 0.35^{\mathrm{ab}}$ & $0.79 \pm 0.09^{\mathrm{b}}$ & $0.80 \pm 0.38$ \\
\hline Tricosylic (C23:0) & $0.40 \pm 0.06^{\mathrm{a}}$ & $0.23 \pm 0.16^{\mathrm{a}}$ & $0.36 \pm 0.03^{\mathrm{a}}$ & $0.33 \pm 0.09$ \\
\hline Lignoceric(C24:0) & $0.35 \pm 0.25^{\mathrm{a}}$ & $0.48 \pm 0.08^{\mathrm{a}}$ & $0.29 \pm 0.18^{\mathrm{a}}$ & $0.37 \pm 0.10$ \\
\hline$\Sigma$ SFA & 20.82 & 26.59 & 24.05 & 23.82 \\
\hline \multicolumn{5}{|c|}{ Monounsaturated fatty acids (MUFAs) } \\
\hline Palmitoleic (C16:1) & $4.25 \pm 0.14^{\mathrm{b}}$ & $4.54 \pm 0.07^{b}$ & $2.90 \pm 0.14^{\mathrm{a}}$ & $3.90 \pm 0.88$ \\
\hline Oleic $(\mathrm{C} 18: 1)$ & $25.23 \pm 0.31^{\mathrm{b}}$ & $26.32 \pm 0.61^{\mathrm{a}}$ & $28.13 \pm 0.54^{b}$ & $26.56 \pm 1.46$ \\
\hline Nonadecylenic(C19:1) & $10.24 \pm 0.77^{b}$ & $14.44 \pm 0.61^{\mathrm{a}}$ & $15.85 \pm 0.12^{\mathrm{a}}$ & $13.51 \pm 2.92$ \\
\hline Paullinic(C20:1) & $2.18 \pm 0.25^{\mathrm{a}}$ & $2.21 \pm 0.09^{\mathrm{a}}$ & $2.49 \pm 0.15^{\mathrm{a}}$ & $2.29 \pm 0.17$ \\
\hline$\Sigma$ MUFA & 41.91 & 47.52 & 49.37 & 46.27 \\
\hline \multicolumn{5}{|c|}{ Polyunsaturated fatty acids (PUFAs) } \\
\hline Linoleic (C18:2 n-6) & $0.64 \pm 0.07^{\mathrm{a}}$ & $0.37 \pm 0.22^{\mathrm{b}}$ & $1.34 \pm 0.09^{\mathrm{c}}$ & $0.78 \pm 0.50$ \\
\hline$\gamma$-Linolenic $(\mathrm{C} 18: 3 \mathrm{n}-3)$ & $0.80 \pm 0.05^{\mathrm{a}}$ & $0.50 \pm 0.04^{\mathrm{b}}$ & $0.36 \pm 0.04^{\mathrm{c}}$ & $0.55 \pm 0.22$ \\
\hline Arachidonic(C20:4 n-6) & $1.87 \pm 0.23^{\mathrm{a}}$ & $1.24 \pm 0.04^{\mathrm{b}}$ & $2.66 \pm 0.20^{\mathrm{c}}$ & $1.92 \pm 0.71$ \\
\hline Eicosapentaenoic (C20:5 n-3) & $3.52 \pm 0.44^{\mathrm{a}}$ & $2.65 \pm 0.46^{\mathrm{b}}$ & $1.56 \pm 0.25^{\mathrm{c}}$ & $2.58 \pm 0.99$ \\
\hline Docosahexaenoic (C22:6 n-3) & $5.27 \pm 0.83^{\mathrm{b}}$ & $4.02 \pm 0.47^{\mathrm{a}}$ & $3.97 \pm 0.04^{\mathrm{a}}$ & $4.42 \pm 0.73$ \\
\hline ¿PUFA & 12.1 & 8.78 & 9.88 & 10.25 \\
\hline$\Sigma \omega-3$ & $10.28 \pm 0.39$ & $6.83 \pm 0.22$ & $6.18 \pm 0.79$ & $7.76 \pm 2.20$ \\
\hline$\Sigma \omega-6$ & $2.55 \pm 0.12$ & $1.27 \pm 0.13$ & $3.85 \pm 0.02$ & $2.56 \pm 1.29$ \\
\hline$\omega-3: \omega-6$ & $2.71 \pm 0.24$ & $2.70 \pm 1.79$ & $1.32 \pm 0.23$ & $2.24 \pm 0.80$ \\
\hline $\mathrm{EPA}+\mathrm{DHA}$ & $9.63 \pm 0.11$ & $6.28 \pm 0.14$ & $5.35 \pm 0.35$ & $7.09 \pm 2.25$ \\
\hline
\end{tabular}

Values are presented as mean \pm standard deviation

Different superscripts within a row correspond to significant difference $(\mathrm{p}<0.05)$

and poor behaviour. Zinc is an important micro-mineral required for growth and development as well as for the proper functioning of immune system, cell growth and healthy skin and also acts as a co-factor for many enzymes required in metabolism. Zinc content of medium and large size groups were higher than the small size group. Similar to iron, zinc content was also high in $R$. rita (37.52 ppm) than S. seenghala $(29.4 \mathrm{ppm}), \quad$ C. batrachus $(12.9 \mathrm{ppm})$, H. fossilis (13.0 ppm), IMCs C. catla (13.0 ppm), L. rohita (19.0 ppm) and C. mrigala (3.0 ppm) (Noor et al., 2013) but lower than small indigenous fish $P$. sophore (51.1 ppm)
(Mahanty et al., 2014). Manganese content was higher than $S$. seenghala $(2.36 \mathrm{ppm})$. Comparative micro mineral $(\mathrm{Fe}, \mathrm{Zn})$ content in different catfishes and IMCs is presented in Fig. 2 a, b.

Although the nutritional composition of fish varies with size, sex and season, only size variation was considered for the study. Seasonal variation was not studied as fish in sufficient quantity was not available in different seasons of a year. Similarly, sex variation was also not included in the present study, as sex is of very little concern for the consumers. However, based on nutritional composition 
Table 4. Mineral composition of different size groups of Rita rita

\begin{tabular}{lllll}
\hline Size group & Small & Medium & Large & Average \\
\hline Marco minerals & \multicolumn{3}{l}{} \\
\hline $\mathrm{Na}$ & $2800 \pm 5.00^{\mathrm{a}}$ & $3100 \pm 7.51^{\mathrm{b}}$ & $2200 \pm 9.02^{\mathrm{c}}$ & $2700.00 \pm 458.26$ \\
$\mathrm{~K}$ & $15900 \pm 2.00^{\mathrm{a}}$ & $17200 \pm 3.06^{\mathrm{b}}$ & $13800 \pm 1.00^{\mathrm{c}}$ & $15633.33 \pm 1715.61$ \\
$\mathrm{Ca}$ & $1100 \pm 1.53^{\mathrm{a}}$ & $1200 \pm 1.53^{\mathrm{b}}$ & $1900 \pm 2.65^{\mathrm{c}}$ & $1400.00 \pm 435.89$ \\
$\mathrm{Mg}$ & $1300 \pm 1.53^{\mathrm{a}}$ & $1300 \pm 2.65^{\mathrm{a}}$ & $1300 \pm 0.58^{\mathrm{a}}$ & $1300.00 \pm 0.00$ \\
$\mathrm{P}$ & $14000 \pm 1.00^{\mathrm{a}}$ & $14100 \pm 5.13^{\mathrm{b}}$ & $11900 \pm 1.53^{\mathrm{c}}$ & $13333.33 \pm 1242.31$ \\
\hline $\mathrm{Micro}$ minerals & & & $64.26 \pm 2.70$ \\
$\mathrm{Fe}$ & $67.15 \pm 1.00^{\mathrm{a}}$ & $63.82 \pm 0.87^{\mathrm{b}}$ & $61.81 \pm 0.54^{\mathrm{c}}$ & $37.52 \pm 4.60$ \\
$\mathrm{Zn}$ & $33.07 \pm 1.24^{\mathrm{a}}$ & $42.25 \pm 0.50^{\mathrm{b}}$ & $37.25 \pm 0.38^{\mathrm{c}}$ & $6.66 \pm 0.56$ \\
$\mathrm{Mn}$ & $\mathrm{ND}$ & $6.26 \pm 0.28^{\mathrm{a}}$ & $7.05 \pm 0.14^{\mathrm{a}}$ & \\
\hline
\end{tabular}

Values are presented as mean \pm standard deviation. Different superscripts within a row correspond to significant difference $(\mathrm{p}<0.05)$ ND : Not detected

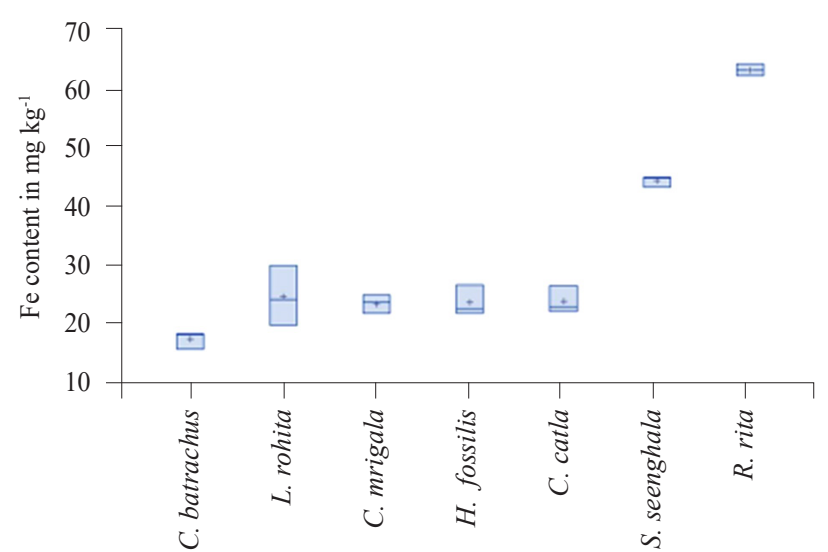

(a)

Fig. 2(a) Comparison of micro minerals (Fe) content of Rita rita with other catfishes ( $S$. seenghala, H. fossilis, C. batrachus, IMCs C. catla, L. rohita and C. mrigala. For comparison, average leucine and phenylalanine content of three size groups of $R$. rita has been used. Data for $S$. seenghala, H. fossilis, C. batrachus and IMCs C. catla, L. rohita and C. mrigala have been taken from Mohanty et al. (2016).

of $R$. rita, it can be concluded that high protein and low fat makes this species a good source of lean meat. It is also a good source of important amino acids like leucine, phenylalanine and glutamic acid and minerals potassium, phosphorous, iron and zinc. Reports indicate that there has been constant decline in the population of the fish both in India and neighbouring countries like Bangladesh. Fishing of juveniles and degradation of breeding grounds have been reported to be the major reasons for the decline (Noor et al., 2013). Special attention is necessary to revive and stabilise the population. The present study shows that the medium size fish is nutritionally superior than the small size group in terms of protein, amino acid and mineral content and provides scientific basis to educate stakeholders about the necessity to conserve the juveniles.

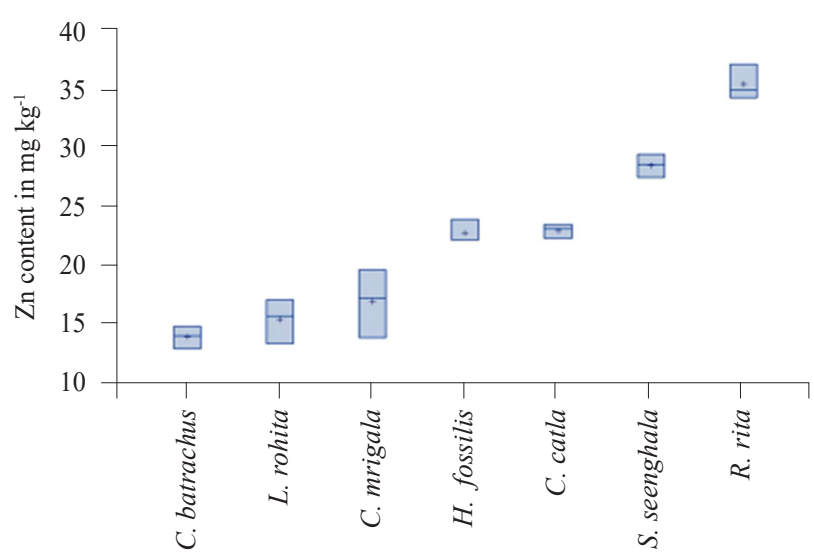

(b)

Fig. 2b. Comparison of micro minerals ( $\mathrm{Zn}$ ) content of Rita rita with other catfishes (S. seenghala, H. fossilis, C. batrachus) and Indian major carps C. catla, L. rohita and C. mrigala.

${ }^{\mathrm{T}} \mathrm{For}$ comparison, average leucine and phenylalanine content of three size groups of $R$. rita have been used ${ }^{t 1}$ Data for S. seenghala, H. fossilis, C. batrachus and the IMCs carps C. catla, L. rohita and C. mrigala have been taken from Mohanty et al., (2016)

\section{Acknowledgements}

This work was supported by the Indian Council of Agricultural Research (ICAR) - Fisheries Science Division under the Outreach Activity on 'Nutrient profiling and evaluation of fish as a dietary component'. The authors are thankful to the Director, ICAR-CIFRI, Barrackpore, for the facilities. The authors (TM, SG, AM and SB) are thankful to the ICAR for the financial assistance.

\section{References}

Ahmed, I. 2011. Effect of dietary niacin on growth and body composition of two Indian major carps rohu, Labeo rohita and mrigal, Cirrhinus mrigala (Hamilton), fingerlings based on dose-response study. Aquac. Int., 19: 567-584.

AOAC 2006. Official methods of analysis. $18^{\text {th }}$ edn. Association of Official Analytical Chemists. Gaithersburg, MD, USA. 
Bandt, J. P. De. and Cynober, L. 2006. Therapeutic use of branched chain amino acids in burn, trauma and sepsis. J. Nutr., 185(1): 308S-313S.

Etzel, M. R. 2004. Manufacture and use of dairy protein fractions J. Nutr., 134(4): 996S-1002S

Folch, J., Less, M. and Stanley, G. H. S. 1957. A simple method for the isolation and purification of total lipids from animal tissues. J. Biol. Chem., 226: 497-509.

Gopakumar, K. 1997. Biochemical composition of Indian food fish. ICAR-Central Institute of Fisheries Technology, Cochin, India.

Ho, B. T. and Paul, D. R. 2009. Fatty acid profile of Tra catfish (Pangasius hypophthalmus) compared to Atlantic salmon (Salmo solar) and Asian seabass (Lates calcarifer). Int. Food Res. J., 16: 501-506.

Ishida, Y., Fujita, T. and Arai, K. 1981. New detection and separation method for amino acid by high performance liquid chromatography. J. Chromatogr., 204: 143-148.

Kamal, D., Khan, A. N., Rahaman, M. A. and Ahamed, F. 2007. Biochemical composition of some small indigenous freshwater fishes from the river Mouri, Khulna, Bangladesh. Pak. J. Biol. Sci., 10: 1559-1561.

Mahanty, A., Ganguly, S., Verma, A., Sahoo, S., Mitra, P., Paria, P., Sharma, A. P., Singh, B. K. and Mohanty, B. P. 2014. Nutrient profile of small indigenous fish Puntius sophore: Proximate composition, amino acid, fatty acid and micronutrient profiles. Natl. Acad. Sci. Lett., 37(1): 39-44.

Memon, N. N., Talpur, F. N. and Bhanger, M. I. 2010. A comparison of proximate composition and fatty acid profile of Indus River fish species. Int. J. Food. Prop., 13: 328-337.

Metcalfe, L. D., Schmitz, A. A. and Petha, J. R. 1966. Rapid preparation of fatty acid esters from lipids for gas chromatographic analysis. Anal. Chem., 38: 514 pp.

Mohanty, B. P., Mahanty, A., Ganguly, S., Sankar, T. V., Chakraborty, K., Anandan, R., Paul, B. N., Sarma, D., Mathew, S., Asha, K. K., Behera, B. K., Aftabuddin, Md., Debnath, D., Vijayagopal, P., Sridhar, N., Akhtar, S., Sahi, N., Mitra, T., Banerjee, S., Paria, P., Das, D., Das, P., Vijayan, K. K., Laxmanan, P. T. and Sharma, A.
P. 2014. Amino acid composition of 27 food fishes and their importance in clinical nutrition. J. Amino Acids, 7. doi.org/10.1155/2014/269797.

Mohanty, B. P., Mitra, T., Banerjee, S., Bhattacharjee, S., Mahanty, A., Ganguly, S., Purohit, G. K., Karunakaran, D. and Mohanty, S. 2015. Proteomic profiling of white muscle from freshwater catfish Rita rita. Fish Physiol. Biochem., 41: 789-802.

Mohanty, B. P., Paria, P., Das, D., Ganguly, S., Mitra, P., Verma, A., Sahoo, S., Mahanty, A., Aftabuddin, Md., Behera, B. K., Sankar, T. V. and Sharma, A. P. 2012. Nutrient profile of giant river-catfish Sperata seenghala (Sykes). Natl. Acad. Sci. Lett., 35: 155-161.

Mohanty, B. P., Sankar, T. V., Ganguly, S., Mahanty, A., Anandan, R., Chakrabarty, K., Paul, B. N., Sarma, D., Dayal, J. S., Mathew S., Asha, K. K., Mitra, T., Karunakaran, D., Chanda, S., Sahi, N., Das, P., Das, P., Akhtar, M. D., Vijayagopal, P. and Sridhar, N. 2016. Micronutrient composition of 35 food fishes from India and their significance in human nutrition. Biol. Trace Elem. Res., 174(22): 448-458. DOI:10.1007/s12011-016-0714-3.

Nguyen, N. H., Ponzoni, R. W., Hamzah, A., Yee, H. Y., Abu-Bakar, K. R. and Khaw, H. L. 2004. Genetics of flesh quality in fish. Fish Aqua., 211: 65-79.

Noor, S. M., Samad, M. A. and Bhuiyan, N. I. M. A. S. 2013. Food and feeding habit of the critically endangered catfish Rita rita (Hamilton) from the Padma River in the north-western region of Bangladesh. Int. J. Adv. Res. Technol., 2: 2278-7763.

Picard, B., Lefevre, F. and Lebret, B. 2012. Meat and fish flesh quality improvement with proteomic applications. Anim. Front., 2: 18-25.

Ramani, M. B. AnnaMercy, T. V., Nair, R. and Sherief, P. M. 2002. Changes in the proximate composition of Labeo rohita (Ham.) exposed to sub-lethal concentrations of monocrotophos. Indian J. Fish., 49(4): 427-432.

Sastry, C. S. P. and Tammuru, M. K. 1985. Spectrophotometric determination of tryptophan in protein. J. Food Sci. Technol., 1(22): 146-147.

Wu, G. 2009. Amino acids: metabolism, functions and nutrition. Amino Acids, 37: 1-17.

Date of Receipt ： 03.03.2017

Date of Acceptance : $\quad 05.06 .2017$ 